\title{
Pembentukkan Karakter Peserta Didik Dalam Pendidikan Islam
}

\author{
Delvi \\ E-mail: delvipbsi@gmail.com \\ Program Studi Pendidikan Bahasa dan Sastra Indonesia, Universitas Riau
}

\section{A. Pengantar}

pendidikan karakter penting dalam dunia pendidikan, hal ini berkaitan dengan fenomena dekadensi moral yang terjadi ditengah-tengah masyarakat maupun lingkungan pemerintah yang semakin meningkat dan beragam. Kriminalitas, ketidak adilan, korupsi, kekerasan pada anak, pelanggaran HAM, menjadi bukti bahwa telah terjadi krisis jati diri dan karakteristik pada bangsa Indonesia. Budi pekerti luhur, kesantunan dan relegiusitas yang dijunjung tinggi dan menjadi budaya bangsa Indonesia selama ini seakan-akan menjadi terasa asing dan jarang ditemui ditengah-tengah masyarakat.

Pendidikan karakter upaya untuk membantu perkembangan jiwa anak-anak baik lahir maupun batin, dari sifat kodratnya menuju kearah peradaban. Yang manusia yang lebih baik. Sebagai conroh dapat ditemukan minsalnya anjuran atau suruhan terhadap anak-anak untuk duduk yang baik tidak berteriak-teriak agar tidak mengganggu orang lain, bersih badan, rapi pakaian, hormat terhadap yang tua, menyayangi yang muda, menghormato irang tua, menolong teman, dan seterusnya merupakan pendidikan berkarakter.

Pendidikan bagi kehidupan manusia merupakan kebutuhan primer atau mutlak yang harus dipenuhi sepanjang hayat tanpa pendidikan mustahil suatu kelompok manusia dapat hidup berkelanjutan denan cita-cita untuk maju, sejahtera dan bahagia menurut konsep pandangan hidup. Pendidikan secara umum adalah usaha sadar manusia untuk menumbuhjan dan mengembangkan potensi-potensi pembawaan baik jasmani maupun roha I sesuai dengan nilai-nilai yang ada didalam masyarakat dan agama.

Perkembangan zaman didunia pendidikan yang terus berubah signifikan sehingga banyak merubah pola piker pendidikan dari pola piker awam dan kaku menjadi lebih modern. Hal tersebut sangat berpengaruh dalam kemajuan pendidikan diindonesia. Karena pentingnya pembentukkan karakter ini utuk membentuk generasi bintang yang kelak mewarisi dan menjaga bangsa ini.

\section{B. Pembahasan}

a. Pengertian pendidikan karakter 
Pendidikan adalah segala situasi hisup yang mempengaruhi pertumbuhan individu sebagai pengalaman belajar yang berlangsug dalam segala lingkungan dan sepanjang hidup. Pendidikan adalah peroses perubahan sikap dan tata laku seseorang atau kelompok orang dalam usaha mendewasakan manusia melalui upaya pengajaran dan pelatihan.

Menurut John Dewey pendidikan merupakan peroses pembentukka kemampuan dasar yang fundamental, baik menyangkut daya pikir atau daya intelegtual maupun daya emosiaonal atau perasaan yang diarahkan pada tabiat manusia dan sesama.

Arti dari karaktet adalah nilai-nilai yang khas baik (tahu nilai kebaikan, mau berbuat baik, nyata berkehidupan baik dan berdampak baik terhadap lingkungan) yang terpateri dalam diri dan terjewantahkan dalam perilaku. Karakter secara koheren memancar dari hasil olah piker olah hati, olah raga, serta lah rasa dan karsa seseorng atau sekelompok orang.

Karakter adalah watak, sifat atau hal-hal yang sangat mendasar yang ada pada diri seseorang yang sifatnya abstrak, orang sering menyebutnya dengan tabiat atau perangai. Hornby dan Parnwel mengatakan bahwa karakter adalah kualitas mental atau moral, kekuatan moral, nama atau reputasi. Menurut Ryan dan Bohlin karakter mengundang tiga unsur pokokyaitu mengetahui kebaikan, mencintai kebaikan, dan melakukan kebaikan. Pendapat tersebut dapat dipahami bahwa karakter merupakan integrasi dari keseluruan ciri pribadi seseorang tingkah laku, kecenderungan, kebiasaan, potensi, dan pola piker yang melekat dalam diri seseorang yang dapat dikembangkan melalui pendidikan.

Muchlas Samani, memaknai karakter sebagai cara berpikir dan berperilaku yang khas tiap individudan bekerja sama, baik dalam lingkungan keluarga, masyarakat, bangsa dan Negara. Individu yang berkarakter adalah individu yang berani berbuat dan bertanggung jawab atas semua perbuatannya dan menyadari akibat buruk yang akan terjadi bila meninggalkan nilai-nilai baik yang berhubungan dengan keimanan, kasih saying, jujur, bekerja keras, tidak mudah putus aasa, dan system nilai lain yang terpuji. 
Pendidikan karakter menurut Zubaedi adalah upaya penananman kecerdasan dalam berpikir, penghayatan dalam bentuk sikap, dan pengamalan dalam bentuk perilaku yang sesuai dalam nilai-nilai luhur yang menjadi jati dirinya, diwujudkan dalam interaksi dengan tuhannya, diri sendiri, antar semuanya, dan lingkungannya.

Pendidikan karakter merupakan upaya-upaya yang dirancang dan dilakasanakan secara sistematis untuk mennamkan nilai-nilai perilaku peserta didik yang berhubungan dengan Tuhan Yang Maha Esa, diri sendiri, semua manusia, lingkungan, dan kebangsaaan yang terwujud dalam dalam pikiran, sikap, perasaan, perkataan dan perbuatan berdasarkan norma agama-agama, hokum, tata karma, budaya dan adat istiadat.

Defenisi pendidikan karakter adalah sebuah usaha untuk mendidik anakanak agar dapat mengambil keputusan dengan bijak dan memperaktekkan dalam kehidupan sehari-hari, sehingga mereka dapat memberikan kontribusi yang positif kepada lingkunganya.

Pendidikan karakter bukanlah berupa materi yang hanya bisa dicatat dan dihafalkan serta tidak dapat dievaluasi dalam jangka waktu yang pendek, tetapi pendidikan karakter merupkan sebuah pembelajaran yang teraplikasi dalam sebuah kegiatan siswa baik disekolah, lingkungan masyarakat dan lingkungan rumah melalui peroses pembiasaan, keteladaanan, dan dilakukan secara berkesinambungan. Oleh karena itu keberhasilan pendidikan berkarakter ini menjadi tanggung jawab bersama anatar sekolah, masyarakat dan orang tua.

b. Tujuan pembentukan pendidikan karakter

Erat kaitannya dengan cita-cita yang ingin menghasilkan siswa yang cerdas dalam ilmu bidang pengetahuan dan teknologi dan terpuji dalam keimanan dan ketakwaannya, maka kini sudah saaatnya sekolah memberikan pendidikan karakter kpada peserta didiknya yaitu kurikulum pembentukkan karakter. Ada beberapa tujuan yang dikaitkan dengan pembentukkan dan pendidikan karakter dalam setting sekolah sebagai berikut: 
1. Menguatkan dan mengembangkan nilai-nilai kehidupan yang dianggap penting dan perlu sehingga menjadi keperibadian atau kepemilikkan peserta didik yang khas sebagaimana nilai-nilai yang dikembangkan.

2. Mengoreksi perilaku peserta didik yang tidak berkesesuaian dengan nilai-nilai yang dikembangkan oleh sekolah.

3. Membangun koneksi yang harmoni dengan keluarga dan masyarakat dalam memern kan tanggungjawab pendidikan karakter secara bersama.

Sejak didni siswa perlu diperkenalkan perilaku positif diantaranya perilaku yang bisa dipercaya, tanggung jawab, perhatian, tidak suka berprasangka buruk, sering berbuat baik, mampu mengendalikan diri saat marah dan kecewa, bisa mengatasi perselisihan, bisa bekerja sama dengan temannya, tidak suka menggertak, sopan dan bisa menghargai orang lain, bisa menghargai diri sendiri, tahu cara meminta bantuan adil, berperan sebagai teman yang baik, bisa mengatakan tidak terhadap ajakan yang tidak baik, bisa mengatasi perselisihan dan lain sebagainya. Tentu saja sederet perilaku tersebut, harus diperkenalkan secara bertahap dan diperaktekkan dalam kehidupan sehari-hari.

Ada beberapa tujuan pendidikan berkarakter. Pertama, mengembangkan potensi efektif peserta didik sebagai manusia dan warga Negara yang memiliki nilai-nilai karakter bangsa. Kedua, mengembangkan kebiasaan dan perilaku peserta didik yang terpuji dan sejalan dengan nilai-nilai universal dan tradisi budaya bangsa yang religius. Ketiga, menanamkan jiwa kepemimpinan, tanggung jawab peserta didik sebagai generasi penerus bangsa. Keempat, mengembangkan kemampuan peserta didik menjadi manusia yang mandiri, kreatif dan berwawasan kebangsaaan. Kelima, mengembangkan lingkungan kehidupan sekolah sebagai lingkungan belajar yang aman, jujur, penuh kreativitasdan persahabatan, dan dengan rasa kebangsaanyang tinggi dan penuh kekuatan. 


\section{c. Bentuk-bentuk pendidikan Karakter}

Seorang guru yanag akan mengerjakan pendidikan karakter juga harus memiliki berbagai karakter yang baik diantaranya:

1. Memiliki pengetahuan keagamaan yang luas dan mengamalkannya dalam kehidupan sehari-hari secra aktif.

2. Menigkatkan kualitas keilmuan seacra berkelanjutan.

3. Bersih jasmani dan rohani.

4. Pemaaaf penyabar dan jujur.

5. Berlaku adil terhadap peserta didik dan semua stakeholder pendidikan.

6. Mempunyai sifat watak dan sifat ketuhanan, yang tercermin dalam pola piker, ucapan dan tingkah laku.

7. Tegas berindak, professional, dan proposional.

8. Tanggap terhadap berbagai kondisi yang mungkin dapat mempengaruhi jiwa, keyakinan dan pola piker peserta didik.

9. Menumbuhkan kesadaran diri sebagai penasehat.

Jadi berdasarkan penjelasan diatas sebelum seorang pendidikan mengajarkan pendidikan karakter dalam proses pembelajaran yang dialai maka ia sendiri juga harus memahami karakter seorang guru yang baik.

Pembentukkan pendidikan karakter dalam islam sebenarnya sudah ada sejak zaman Rasulullah SAW. Hal ini terbukti dari perintah Allah bahwa tugas pertama dan utama Rasulullah adalah sebagai penyempurna akhlal bagi umatnya. Pembahasan substansi makna dari karakter sama dengan konsep akhlak dalam islam, keduanya membahas tentang perbuatan perilaku manusia. Al-Ghazali jika akhlak adalah suatau sikap yang mengakar dalam jiwa yang dari lahirnya berbagai perbuatan dengan mudah dan gampang tanpa perlu adanya pemikiran dan pertimbangan. Suwito menyebutkan bahwa akhlak sering disebut juga ilmu tingkah laku atau perangai, karena dengan ilmu tersebut akan diperoleh ilmu pengetahuan tentang keutamaan-keutamaanjiwa; bagaimana cra memperolehnya dan bagaimana cara membersihkan jiwa yang telah kotor. 
Akhlak atau karakter dalam islam adalah sasaran utama dalam pendidikan. Hal ini dapat dilihat dari beberapa hadis nabi yang menjelaskan tentang, keutamaan pendidikan akhlak salah satunya hadis berikut ini "ajarilah anakanakmu kebaikan dan didiklah mereka”, konsep pendidikan didalam inslam memandang bahwa manusia dilahirkan dengan membawa potensi lahiriah yaitu: potensi berbuat baik kepada alam, potensi berbuat kerusakan terhadap alam, potensi ketuhanan yang memiliki fungsi-fungsi non fisik. Ketiga potensi tersebut kemudian diserahkan kembali perkembangan kepada manusia.

\section{Penutup}

Penanaman karakter pada anak sejak dini berarti ikut mempersiapkan generasi bangsa yang berkarakter, mereka adalah calon generasi bangsa yang diharapkan mampu memimpin bangsa dan menjadikan Negara yang berperadaban, menjujung tinggi nilai-nilai luhur bangsa dan akhlak dan budi perkerti yang baik serta menjai generasi yang berilmu pengetahuan tnggi dan menghiasi dirinya dengan iman dan taqwa.

\section{Referensi}

Jurnal Al-Ulum Volume, 13 Nomor 1, Juni 2013 hal 25-38

Permendiknas No 22 Tahun 2006, tentang standar isi untuk satuan pendidikan tingkat dasar dan menegah, hal 2

Abidin Ibnu Rusn, Pemikiran Al-Gazali tentang pendidikan (Yogyakarta: Pustaka Pelajar, 1998), hal 99

Jurnal Tarbawiyah Pendidikan Kearah Pembentkkan Karakter Volume 11 Nomor 2 Edisi Januari-Juli 2014 
Agus Sukrisman, Desember 2014 "Pembentukkan Karakter Peserta Didik Dilembaga Pendidikan Islam Al-Izzah Kota Sorong” Pendidikan dan Keguruan, Universitas Islam Negeri Alauddin Makassar

\section{Data Penulis}

Delvi, lahir di Bagansiapiapi, 15 September 2000. Saya melanjutkan akademik pada tahun 2018 Jurusan Pendidikan Bahasa dan Seni di Program Pendidikan Bahasa dan Sastra Indonesia FKIP Universitas Riau melalui jalur SNMPTN

Hp/Wa : 082283599471

E-mail : delvipbsi@gmail.com 